\title{
Bayi Baru Lahir dengan Kelainan Kongenital berupa Meningoensefalokel Parietal: Sebuah Laporan Kasus
}

\author{
Danny Yovita Maharani ${ }^{1}$, Arninda Rahman ${ }^{2 *}$, Nurul Islamy ${ }^{3}$, Javedh Iqbal $^{3}$ \\ ${ }^{1)}$ Fakultas Kedokteran, Universitas Lampung \\ ${ }^{2)}$ Fakultas Kedokteran, Universitas Lampung, arninda070996@ gmail.com \\ ${ }^{3)}$ Bagian Obstetri dan Ginekologi, RSUD Dr. H. Abdul Moeloek
}

\begin{abstract}
ABSTRAK
Meningoensefalokel merupakan kelainan kongenital yang jarang terjadi dengan insiden dari 1-4 kasus per 10.000 kelahiran hidup. Meningoensefalokel adalah kelainan kongenital akibat defek tuba neuralis. Pasien laki-laki lahir cukup bulan dengan sectio caesarea atas indikasi kelainan kongenital. Pada pasien terdapat benjolan di samping kepala sejak dilahirkan. Ibu pasien mengaku kurang mengkonsumsi asam folat selama kehamilan. Pada pemeriksaan fisik ditemukan benjolan pada oksipital dengan ukuran $15 x 15 \mathrm{~cm}$. Tidak ditemukan adanya darah dan nanah. Terdapat adanya fluktuasi dan menandakan adanya transluminasi. CT Scan kepala tanpa kontras didapatkan meningoensefalokel daerah parietal dengan defek daerah tersebut. Pada pasien diberikan penatalaksanaan berupa balut masa dengan kasa steril/24 jam, antibiotik, analgetik dan pemenuhan kebutuhan cairan pasien. Pada pasien dilakukan operasi bedah saraf yaitu reseksi meningoensefalokel transkranial diikuti dengan pengamatan yang cermat dan pemantauan tanda vital bayi selama operasi. Setelah operasi, tidak ada bukti infeksi serebrospinal dan kebocoran cairan serebrospinal. Lukanya sembuh dengan sempurna dan tidak ada tanda-tanda peningkatan tekanan intrakranial selama rawat inap. Lingkar kepala diukur dan dibuat grafik dua kali seminggu. Keadaan pasien di follow up dan menunjukan perbaikan setiap harinya. Metode penelitian menggunakan studi kasus penelaahan empiris yang menyelidiki suatu gejala dalam latar kehidupan nyata dan didapatkan kesimpulan bahwa pada pasien tidak terlihat adanya keterlibatan otak di dalam kantung meningoesenfalokel parietal dan tidak terdapat gambaran hidrosefalus, sehingga pasien ini memiliki prognosis yang baik. Saran terhadap penelitan lanjutan adalah dengan melihat prognosis dan komplikasi pada pasien sehingga dapat dinilai diawal dan menjadi pertimbangan dokter dalam menentukan tindakan yang akan dilakukan.
\end{abstract}

Kata kunci: Meningoensefalokel, Kelainan Kongenital, Asam Folat, Operasi Bedah Saraf

\begin{abstract}
Meningoencephalocele is a rare congenital disorder with an incidence of 1-4 cases per 10,000 live births. Meningoencephalocele is a congenital abnormality resulting from a neural tube defect. The male patient was born at term with cesarean section on indication of congenital abnormalities. The patient had a lump on the side of the head since birth. The patient's mother admitted that she did not consume enough folic acid during pregnancy. On physical examination found a lump in the occipital with a size of $15 x 15 \mathrm{~cm}$. No blood or pus was found. There is a fluctuation and indicates a transillumination. A CT scan of the head without contrast revealed a parietal meningoencephalocele with a regional defect. The patient was given management in the form of a mass dressing with sterile gauze/24 hours, antibiotics, analgesics and meeting the patient's fluid needs. The patient underwent neurosurgical surgery, namely resection of transcranial meningoencephalocele followed by careful observation and monitoring of the baby's vital signs during surgery. After surgery, there was no evidence of cerebrospinal infection and leakage of cerebrospinal fluid. The wound healed completely and there was no sign of increased intracranial pressure during hospitalization. Head circumference was measured and graphed twice a week. The patient's condition was followed up and showed improvement every day. The research method used an empirical case study that investigated a symptom in a real-life setting and it was concluded that the patient had no visible involvement of the brain in the parietal meningoencephalocele and no hydrocephalus, so this patient had a good prognosis. Suggestions for further research is to look at the prognosis and complications in patients so that they can be assessed early and become a doctor's consideration in determining the action to be taken.
\end{abstract}

Keywords: Meningoenchepalocele, Congenital Anomalies, Folic Acid, Neurosurgery

* Korespondensi Author: Arninda Rahman, Jl. Hayam Wuruk, gg. Binamarga No. 28 Kedamaian, Bandar Lampung. HP 082233291996.e-mail arninda070996@gmail.com

\section{PENDAHULUAN}

Meningoensefalokel

merupakan

kelainan kongenital yang jarang terjadi dengan insiden dari 1-4 kasus per 10.000 kelahiran hidup. Sekitar $75 \%$ oksipital, $13 \%$ frontal dan $12 \%$ terjadi di daerah parietal. 
Meningoensefalokel (meningoencepha locele) atau disebut juga ensefalokel (encephalocele) adalah kelainan kongenital akibat defek tuba neuralis. Defek tuba neuralis ini di daerah kaudal akan menyebabkan spina bifida dan di daerah kranial akan menyebabkan defek tulang kranium disebut cranium bifidum. Hal ini dimulai pada masa embrio pada minggu ke III sampai dengan minggu ke IV; tidak menutupnya tuba neuralis pada ujung kranial dapat menimbulkan herniasi jaringan saraf pusat. Meningoensefalokel dapat terjadi di seluruh bagian tengkorak, tetapi yang paling sering terjadi di regio occipital ${ }^{1,2}$.

Herniasi atau benjolan ini dapat berisi meningen dan cairan serebrospinal saja disebut meningokel kranial, dapat juga berisi meningen, cairan serebrospinal dan jaringan/parenkim otak disebut meningoensefalokel. Secara umum herniasi melalui defek kranium disebut meningoensefalokel, walaupun sebenarnya berbeda patologi, pengobatan dan prognosisnya. Sekitar $12 \%$ meningoensefalokel didapatkan di regio parietal, dapat terlihat sebagai kantong kecil bertangkai atau struktur seperti kista besar, dapat lebih besar daripada kranium; tertutup oleh kulit seluruhnya; kadang-kadang di tempat-tempat tertentu hanya dilapisi oleh membran tipis seperti kertas perkamen (Gambar 1) $)^{1,2}$.

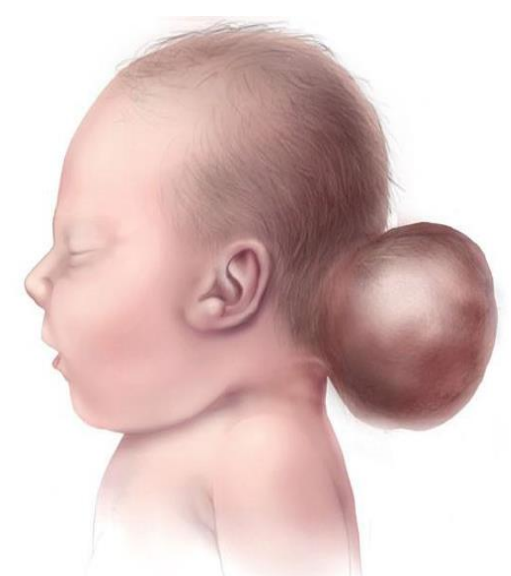

Gambar 1. Meningoensefalokel pada region parietal.(3)

Isi meningoensefalokel dapat diketahui dengan transiluminasi dan USG, pada pemeriksaan mikroskopis, biasanya akan didapatkan jaringan otak abnormal/displasia. Insiden meningoensefalokel 1-5 per 10000 bayi lahir hidup; paling kecil dari seluruh penyakit defek tuba neuralis (8\% - 19\%). Di Eropa dan Amerika hampir 80\% - 90\% meningoensefalokel terdapat di regio oksipital; meningoensefalokel di daerah anterior (frontal, nasofrontal, nasofaringeal) lebih sering di Asia Tenggara ${ }^{4}$.

Gejala klinis sangat bervariasi tergantung malformasi serebral yang terjadi, termasuk hidrosefalus dan banyaknya jaringan otak yang mengalami displasia dan masuk ke dalam kantung meningoensefalokel. Jika hanya mengandung meningen saja, prognosisnya lebih baik dan dapat berkembang normal. Gejalagejala sehubungan dengan malformasi otak adalah mental retardasi, ataxia spastik, kejang, buta dan gangguan gerakan bola mata. Sebenarnya diagnosis perinatal dapat ditegakkan dengan pemeriksaan USG, alfa feto protein cairan amnion dan serum ibu ${ }^{5,6}$.

Pemeriksaan radiologis dilakukan untuk menilai struktur patologis sefalokel: daerah defek tulang, ukuran serta isi sefalokel, ada atau tidaknya anomali SSP, dan dinamika CSS. Lubang defek tulang pada meningoensefalokel oksipital mudah dikenal pada foto polos tengkorak. CT scan memperlihatkan tidak hanya isi kantung namun semua kelainan intrakranial yang bersamaan. Angiografi serebral mungkin perlu untuk membedakan meningoensefalokel oksipital dari kantung dorsal holoprosensefali; holoprosensefali didiagnosis oleh adanya arteria serebral anterior azigos ${ }^{1,5}$.

Pada meningoensefalokel yang ditutupi kulit kepala yang baik, operasi dapat ditunda sampai keadaan anak stabil. Tujuan operasi adalah menutup defek (watertight dural closure), eksisi masa otak yang herniasi serta memelihara fungsi otak. Defek tulang yang cukup besar dapat diperbaiki dengan wire mesh, plastik atau tulang, tetapi jarang diperlukan. Pemberian makan per oral dapat diberikan 4 jam setelah pembedahan. Lingkar kepala diukur dan dibuat grafik sekali atau dua kali seminggu. Sering kali terdapat peningkatan awal dalam pengukuran setelah penutupan cacat spinal dan jika peningkatan ini berlanjut dan terjadi perkembangan hidrochephalus maka harus diberikan terapi yang sesuai $^{7,8}$. 


\section{Kasus}

An. B, pasien laki-laki lahir cukup bulan dengan sectio caesarea atas indikasi kelainan bawaan pada pukul 11.30 WIB pada tanggal 26 Januari 2021. Pada pasien terdapat benjolan di samping kepala sejak dilahirkan. Sebelumnya, pasien sudah didiagnosis meningoensefalokel pada saat di dalam kandungan. Benjolan di samping kepala berukuran $\pm 15 \times 15 \mathrm{~cm}$. (Gambar 2). Benjolan tidak mengeluarkan darah maupun nanah. Pasien merupakan anak pertama. Pada saat lahir pasien menangis kuat, bergerak aktif dan tidak kebiruan. Pasien juga tidak mengalami kejang atau sesak sejak lahir. Tidak terdapat gangguan BAB dan BAK pada pasien. Tidak terdapat kelainan bawaan lainnya.

Ibu pasien mengaku dalam keadaan sehat selama hamil. Ibu pasien tidak melakukan pemeriksaan kehamilan secara rutin. Ibu pasien menyangkan mengkonsumsi obat-obatan. Saat lahir, pasien langsung menangis, bergerak aktif, dan tidak kebiruan. BB pasien saat lahir adalah 2900 gr dan PB pasien $47 \mathrm{~cm}$. Selama perawatan di PICU pasien mendapatkan kebutuhan nutrisi (ASI dan nutrisi parenteral) sesuai berat badan. Pasien sudah mendapatkan imunisasi BCG dan injeksi Vitamin $\mathrm{K}$ saat lahir. Tidak terdapat kelainan bawaan pada keluarga.

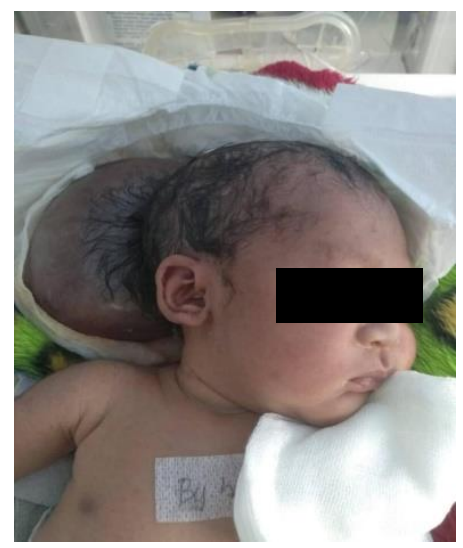

Gambar 2. Meningoensefalokel Parietal pada Bayi Laki-laki yang baru lahir

Pada pemeriksaan fisik didapatkan keadaan umum tampak sakit sedang, kesadaran compos mentis, nadi $138 \mathrm{x} /$ menit, respirasi 48 $\mathrm{x} / \mathrm{menit}$, suhu aksila $37,1^{\circ} \mathrm{C}$, BB 2900 gram dan TB $47 \mathrm{~cm}$. Pada pemeriksaan mata, mulut, tht, leher, thorak, jantung, abdomen dan ekstremitas tidak didapatkan kelainan. Pada kepala, tampak benjolan pada parietal dengan ukuran $15 \times 15 \mathrm{~cm}$, tidak terdapat nanah dan darah. Bejolan bersifat fluktuatif dan menunjukan transluminasi positif. Pembengkakan bersifat kistik dan membesar saat menangis. Fontanela anterior dan posterior masih terbuka.

Pemeriksaan neurologis menunjukan bahwa pasien dalam keadaan sadar dan memiliki refleks menghisap yang normal. Tidak ada kelemahan anggota tubuh dan otot yang bagus nada. Refleks primitif normal dan simetris. Refleks cahayanya normal. Pemeriksaan penunjang pasien berupa darah lengkap dengan hasil hemoglobin 19,8 g/dL, hematokrit $57 \%$, leukosit $15.400 / \mu \mathrm{L}$, eritrosit $5,5 \mathrm{juta} / \mu \mathrm{L}$, trombosit $110.000 / \mu \mathrm{L}$, ureum $36 \mathrm{mg} / \mathrm{dL}$, kreatinin $\quad 0,67 \quad \mathrm{mg} / \mathrm{dL}, \quad$ aspartase aminotransferase (AST) $30 \mathrm{U} / \mathrm{L}$, alanine aminotransferase (ALT) $28 \mathrm{U} / \mathrm{L}$ dan albumin 3,7 $\mathrm{mg} / \mathrm{dL}$.

Pada pemeriksaan USG kehamilan didapatkan gambaaran berupa kepala defleksi, masa kistik $7 \mathrm{~cm}$ dan jaringan Otak yang memberikan kesan meningoensefalokel parietal (Gambar 3). Pada pemeriksaan CT scan kepala tanpa kontras didapatkan meningoensefalokel daerah parietal dengan defek daerah tersebut, deviasi midline ke kiri (Gambar 4). Berdasarkan hasil anamnesis, pemeriksaan fisik, pemeriksaan penunjang pada pasien ini dapat ditegakkan diagnosis Meningoensefalitis Oksipital.

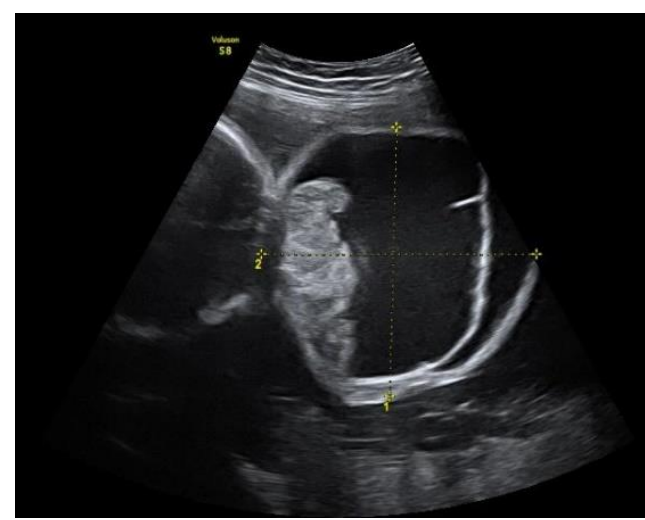

Gambar 5. USG kehamilan usia 37 minggu 


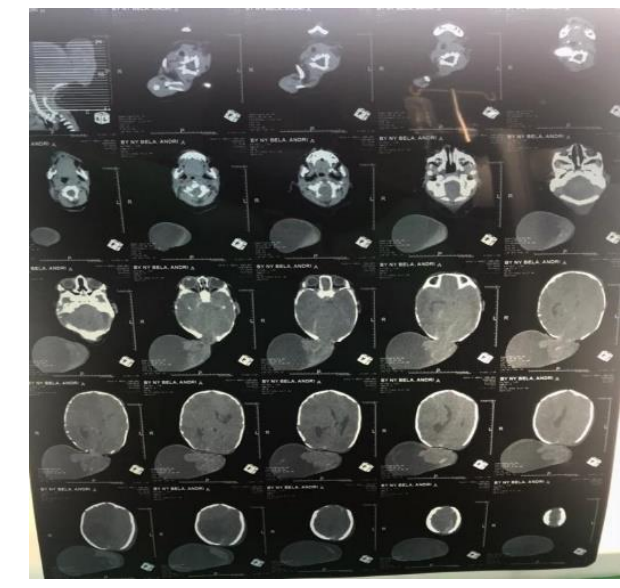

Gambar 4. CT Scan Kepala Tanpa Kontras

Pada pasien diberikan penatalaksanaan berupa balut masa dengan kasa steril/24 jam, injeksi ampisulbac $15 \mathrm{mg} / 12 \mathrm{jam}$, gentamisin 15 $\mathrm{mg} / 36 \mathrm{jam}$, PCT flc $60 \mathrm{cc} / 8$ jam, pemenuhan kebutuhan cairan pasien dengan $\mathrm{D} 10 \%, \mathrm{NaCl}$ 3\%, $\mathrm{KCl} 7 \%$, Ca Glukonas dan Aminosteril 6\%. Dilakukan operasi bedah saraf pada pasien yaitu reseksi meningoensefalokel transkranial. Pasien dibaringkan dalam posisi tengkurap posisi di atas meja operasi, didukung di atas gulungan donat lembut dan pasien dalam anestesi umum (GA). Pembedahan bertujuan untuk membuat eksisi dan untuk perbaiki kantung. Eksisi dilakukan oleh menghilangkan jaringan ekstrakranial lalu tutup defek dengan tutup durafasial.

Dilakukan pengamatan yang cermat dan pemantauan tanda vital bayi selama operasi. Setelah operasi, tidak ada bukti infeksi serebrospinal dan kebocoran cairan serebrospinal. Lukanya sembuh dengan sempurna, dan tidak ada tanda-tanda peningkatan tekanan intrakranial selama rawat inap. Lingkar kepala diukur dan dibuat grafik sekali atau dua kali seminggu. Keadaan pasien di follow up dan menunjukan perbaikan setiap harinya (Gambar $5)$.

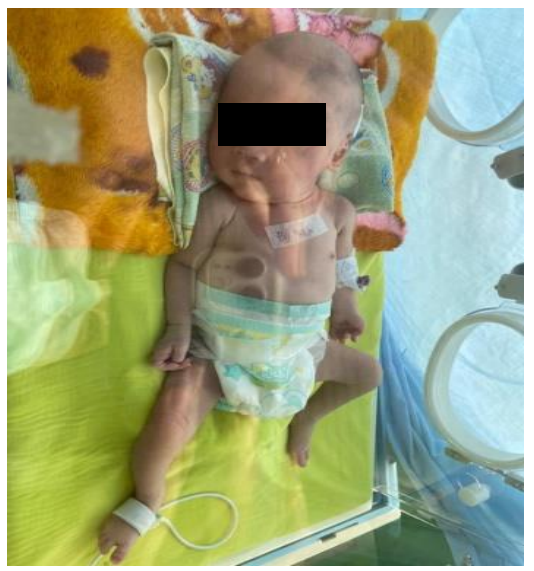

Gambar 5. Keadaan pasien post reseksi meningoensefalokel transkranial hari ke-2

\section{METODOLOGI}

Metode yang digunakan adalah menggunakan studi kasus. Studi kasus adalah suatu strategi riset, penelaahan empiris yang menyelidiki suatu gejala dalam latar kehidupan nyata. Strategi ini dapat menyertakan bukti kuatitatif yang bersandar pada berbagai sumber dan perkembangan sebelumnya dari proposisi teoretis. Dalam riset yang menggunakan metode ini, dilakukan pemeriksaan longitudinal yang mendalam terhadap suatu keadaan atau kejadian yang disebut sebagai kasus dengan menggunakan cara-cara yang sistematis dalam melakukan pengamatan, pengumpulan data, analisis informasi, dan pelaporan hasilnya.

\section{HASIL DAN PEMBAHASAN}

Meningoensefalokel disebabkan oleh kegagalan penutupan tabung saraf selama perkembangan janin. Kegagalan penutupan tabung saraf ini disebabkan oleh gangguan pembentukan tulang kranium saat dalam uterus seperti kurangnya asupan asam folat selama kehamilan, adanya infeksi pada saat kehamilan terutama infeksi TORCH, mutasi gen (terpapar bahan radiologi), obat - obatan yang mengandung bahan yang terotegenik. Meningoensefalokel juga disebabkan oleh defek tulang kepala, biasanya terjadi dibagian occipitalis, kadang - kadang juga dibagian nasal, frontal, atau parietal (9). Pada pasien terdapat benjolan di kepala bagian parietal sejak dilahirkan. Ibu pasien mengaku kurang 
mengkonsumsi asam folat selama kehamilan. Asam folat bermanfaat dalam proses penutupan neural tube, sehingga kekurangan asam folat dalam kehamilan dapat meningkatkan risiko terjadinya defek tabung saraf ${ }^{10}$.

Meningoensefalokel ditandai dengan adanya penonjolan meningens (selaput otak) dan otak yang berbentuk seperti kantung melalui suatu lubang pada tulang tengkorak. ${ }^{10}$ Pada pemeriksaan kepala didapatkan simetris, normocephal, tidak ditemukannya edema, dan sianosis. Tampak Benjolan pada oksipital dengan ukuran $15 \times 15 \mathrm{~cm}$. Tidak ditemukannya darah dan nanah. Benjolan bersifat fluktuatif dan menunjukan transluminasi positif. Pemeriksaan ini, menunjukan masa kistik yang memberikan gambaran masa berisi cairan di dalam jaringan lunak. Masa kisitik ini disebabkan karena adanya defek pada neural tube sehingga meningens dan jaringan otak tak tertutup dengan sempurna ${ }^{11}$.

Umumnya neonatus dengan meningoensefalokel, aktif dan ada tidak ada tanda-tanda cacat neurologis. Neonatus memiliki refleks primitif yang positif dan bagus, refleks menghisap, meski sedikit terhambat oleh massa. Biasanya meningoensefalokel disertai kraniofasial lainnya kelainan atau malformasi otak. Gejala ini termasuk cacat neurologis, hidrosefalus, kelumpuhan, kejang, mikrosefali, ataksia, gangguan berdasarkan, masalah visual, mental dan retardasi pertumbuhan. ${ }^{9,11}$ Pada saat lahir pasien menangis kuat, bergerak aktif dan tidak kebiruan. Pasien juga tidak mengalami kejang atau sesak sejak lahir. Hal ini menandakan tidak terdapat kelainan neurologis yang dapat disebabkan karena kelainan kongenital akibat defek tabung saraf.

Kejadian mesensefalokel menurunkan tingkat kelangsungan hidup bayi baru lahir menjadi $21 \%$, dan hanya setengah dari mereka yang akan bertahan. Sekitar $75 \%$ dari mereka yang selamat akan menderita dari keterbelakangan mental, dan sekitar 3\% mengalami kekambuhan setelah operasi. Dalam hal ini, diagnosis meningoensefalokel berdasarkan riwayat kesehatan dan pemeriksaan fisik dan dikonfirmasi dengan CT-scan kepala (12), (13). Pada pemeriksaan USG kehamilan didapatkan gambaaran berupa kepala defleksi, masa kistik $7 \mathrm{~cm}$ dan jaringan otak yang memberikan kesan meningoensefalokel parietal. Pada pasien, pemeriksaan CT scan kepala tanpa kontras didapatkan meningoensefalokel daerah parietal dengan defek daerah tersebut, deviasi midline ke kiri. Dari pemeriksaan pencitraan tersebut dapat membantu menegakkan diagnosis meningoensefalokel parietal.

Pembalutan masa dengan kasa steril segera setelah lahir pada daerah yang terdapat masa atau lesi yang terpapar dilakukan untuk mencegah jaringan saraf yang terpapar menjadi kering. Perawatan pra-bedah neonatus rutin dengan penekanan khusus pada saat mempertahan suhu tubuh yang dapat menurun dengan cepat ${ }^{14}$.

Pemberian cairan pada neonatus baru lahir harus disesuaikan dengan kebutuhan setiap harinya. Pada hari pertama kebidupan dapat diberikan nutrisi parenteral berupa D 10\% dan ASI peroral. Perhitungan kebutuhan cairan pada neonatus hari ke-1 adalah $60-80 \mathrm{ml} / \mathrm{kg} / \mathrm{hari}$. Sehingga dapat dihitung cairan hari ke-1 pasien ini adalah $240 \mathrm{ml} / \mathrm{hari}(80 \mathrm{mlx} 2,9 \mathrm{~kg}) / \mathrm{hari}$. Pada pasien diberikan cairan parenteral D $10 \% \quad 160$ cc/hari (6,7 cc/jam) dan ASI peroral sebanyak 80 cc (10 cc/3 jam). Kebutuhan cairan pada hari ke2 hingga hari ke-7 yaitu 100-120 ml/kg/hari. Sehingga pada hari ke-2 hingga ke-7 dapat dihitung cairan pasien ini adalah $360 \mathrm{ml} / \mathrm{hari}$ $(120 \mathrm{mlx} 2,9 \mathrm{~kg}) / \mathrm{hari}$. Cairan ini mengandung cairan parenteral D 10\% $233 \mathrm{cc}(9,7 \mathrm{cc} / \mathrm{jam})$, $\mathrm{NaCl} 3 \% 12 \mathrm{cc} /$ hari $(4 \mathrm{ccx} 2,9 \mathrm{~kg}), \mathrm{KCl} 7 \% 6 \mathrm{cc}(2$ ccx2,9 kg), Ca Glukonas 9 cc $(3 \mathrm{ccx} 2,9 \mathrm{~kg})$ dan aminosteril 6\% $100 \mathrm{cc}(2 \mathrm{grx} 2,9 \mathrm{~kg})(3)^{15}$.

Pada pasien diberikan paracetamol infus dengan dosis $60 \mathrm{mg} / \mathrm{kgBB} /$ hari sebagai antipiretik dan analgetik pada pasien. Pada pasien juga diberikan antibiotik berupa Anpisulbac dan Gentamisin Injeksi. Ampicillin Sulbactam merupakan antibiotic kombinasi yang digunakan untuk mengatasi resistensi bakteri produsen enzim betalaktamase terhadap ampisilin. Ampicillin adalah antibiotic beta lactam yang termasuk golongan penicillin sedangkan sulbactam adalah obat yang bekerja dengan cara menghambat kerja enzim betalaktamase yang diproduksi oleh bakteri, sehingga penambahan sulbactam akan meningkatkan potensi ampicillin. 
Ampicillin/Sulbactam dapat digunakan pada infeksi bedah yaitu untuk profilaksis dan pengobatan akibat operasi bedah ${ }^{16}$.

Gentamicin adalah antibiotic yang digunakan untuk mengobati infeksi bakteri antara lain septicemia (suatu kondisi dimana seseorang mengalami keracunan darah akibat bakteri dalam jumlah besar masuk ke dalam aliran darah) dan sepsis (kondisi medis yang disebabkan oleh timbulnya peradangan karaena infeksi yang masuk dalam tubuh) pada neonatus ${ }^{17}$. Sehingga antibiotik tersebut diindikasikan pada kasus ini.

Penatalaksanaan meningoensefalokel tergantung dari isi dan luas dari anomali. Pada meningokel oksipital, di mana kantung tidak mengandung jaringan saraf, hasil dari pembedahan hampir selalu baik. Tetapi pada meningoensefalokel yang berisi jaringan otak biasanya diakhiri dengan kematian dari anak. Hampir semua meningoensefalokel memerlukan intervensi bedah saraf, kecuali massanya terlalu besar dan dijumpai mikrosefali yang jelas. Bila mungkin, tindakan bedah sedini mungkin untuk menghindari infeksi, apalagi jika ada perlukaan di kepala. Pada meningoensefalokel yang ditutupi kulit kepala yang baik, operasi dapat ditunda sampai keadaan anak stabil. Tujuan operasi adalah menutup defek (watertight dural closure), eksisi masa otak yang herniasi serta memelihara fungsi otak ${ }^{18}$.

Tindakan operasi bedah saraf pada pasien ini yaitu reseksi menioensefalokel transkranial, pasien dibaringkan dalam posisi tengkurap posisi di atas meja operasi, didukung di atas gulungan donat lembut. Pembedahan bertujuan untuk membuat eksisi dan untuk perbaiki kantung. Kemudian, eksisi dilakukan oleh menghilangkan jaringan ekstrakranial lalu tutup defek dengan tutup durafasial. Pengamatan yang cermat dan memantau tanda vital bayi itu dilakukan selama operasi.

Prognosis menigoesenfalokel tergantung pada lokasi, ukuran, dan isi kantung ${ }^{19}$. Pada pasien ini tidak terlihat adanya keterlibatan otak di dalam kantung meningoesenfalokel parietal dan tidak terdapat gambaran hidrosefalus. Sehingga pasien ini memiliki prognosis yang baik.
Komplikasi paling umum dari operasi tersebut adalah infeksi, meningitis, kerusakan otak, dan hidrosefalus. Kekambuhan bisa terjadi setelah operasi. Disfungsi visual, kelainan motorik dan masalah kecerdasan biasa terjadi di kasus ini. Angka kematian kasus ini sekitar 30\% meskipun sudah diaplikasikan perawatan yang tepat ${ }^{20}$. Setelah operasi, tidak ada bukti infeksi serebrospinal dan kebocoran cairan serebrospinal pada pasien. Lukanya sembuh dengan sempurna, dan tidak ada tanda-tanda peningkatan tekanan intrakranial selama rawat inap. Lingkar kepala diukur dan dibuat grafik sekali atau dua kali seminggu. Keadaan pasien di follow up dan menunjukan perbaikan setiap harinya.

\section{SIMPULAN DAN SARAN}

Penatalaksanaan yang sesuai dengan melakukan pemeriksaan fisik dan penunjang yang berkala dapat memprediksi keberhasilan tindakan operasi namun prognosis dapat ditentukan setelah dilakukan pembedahan dan melihat sampai sejauh mana persebaran penyakit terjadi. Prognosis menigoesenfalokel tergantung pada lokasi, ukuran, dan isi kantung. Tidak adanya otak jaringan di kantung adalah prognostik yang baik. Prognosis yang buruk termasuk menigoesenfalokel posterior, adanya hidrosefalus dan sistemik lainnya kelainan. Penderita ensefalokel anterior memiliki tingkat kelangsungan hidup yang lebih tinggi, dibandingkan dengan mereka yang memiliki ensefalokel posterior. Prognosis buruk karena herniasi otak jaringan, yang kemungkinan besar akan menyebabkan beberapa cacat neurologis yang serius. Itu keterlibatan sistem ventrikel di kasus ini dapat menyebabkan hidrosefalus, yang akan memperburuk prognosis.

Penelitian lebih lanjut dapat mengembangkan tindakan non invasif maupun invasif yang tepat walaupaun jaringan otak telah terlibat sehingga dapat menyelamatkan lebih banyak lagi anak yang terdiagnosis oleh penyakit ini.

\section{UCAPAN TERIMAKASIH}

Ucapan terimakasih ditujukan kepada seluruh dokter spesialis Bedah Syaraf Dr. H 
Abdul Moeloek atas bimbingan dan pengetahuan yang telah diberikan, uacapan terimakasih juga diucapkan terhadap dan perawat yang telah memberikan ilmu dan pengetahuan sehingga laporan kasus ini dapat tertulis dengan baik. Kami berharap laporan kasus ini dapat berguna dan bermanfaat bagi sesama dalam mengembangkan ilmu pengetahuan.

\section{REFERENSI}

1. Kliegman RM, Toth H, Bordini BJ, Basel D. Nelson Pediatric Symptom-Based Diagnosis EBook. Elsevier Health Sciences; 2017.

2. Gupte S. The short textbook of pediatrics. JP Medical Ltd; 2016.

3. Hull D, Johnston DI. Dasar dasar pediatri ed 3. In EGC; 2008.

4. Elzouki AY, Harfi HA, Nazer H, Oh W, Stapleton F, Whitley RJ. Textbook of clinical pediatrics. Springer Science \& Business Media; 2011.

5. Kosmidou P, Ntarladima V, Katsimantas A, Filippou D, Georgalas C. Endoscopic Surgical Repair of a Giant, Postoperative, Neglected Meningoencephalocele. Cureus. 2020;12(1).

6. Puri P, Höllwarth ME. Pediatric surgery: diagnosis and management. Springer Science \& Business Media; 2009.

7. Cavalheiro S, da Costa MDS, Nicácio JM, Dastoli PA, Suriano IC, Barbosa MM, et al. Fetal surgery for occipital encephalocele. Journal of Neurosurgery: Pediatrics. 2020;26(6):605-12.

8. Ong AG, Rolnik DL, Menezes M, Meagher S. Early Diagnosis and Differences in Progression of Fetal Encephalocele. Journal of Ultrasound in Medicine. 2020;39(7):1435-40.

9. Levene MI, Chervenak FA. Fetal and neonatal neurology and neurosurgery. Elsevier Health Sciences; 2009.

10. Setiawan MR, Rohmani A, Kurniati ID, Ratnaningrum K, Basuki R. BUKU AJAR: ILMU BEDAH. 2017;

11. Thompson HM, Schlosser RJ, Walsh EM, Cho DY, Grayson JW, Karnezis TT, et al. Current management of congenital anterior cranial base encephaloceles. International journal of pediatric otorhinolaryngology. 2020;131:109868.

12. Pahuja HD, Deshmukh SR, Lande S, Palsodkar S, Bhure A. Anaesthetic management of neonate with giant occipital meningoencephalocele: Case report. Egyptian Journal of Anaesthesia. 2015;31(4):331-4.

13. Cruz AJM, De Jesus O. Encephalocele. StatPearls [Internet]. 2020;

14. Markovic I, Bosnjakovic P, Milenkovic Z. Occipital Encephalocele: Cause, Incidence, Neuroimaging and Surgical Management. Current pediatric reviews. 2020;16(3):200-5.
15. Duggan C, Watkins JB, Koletzko B, Walker WA. Nutrition in pediatrics: basic science, clinical applications. Vol. 1. PMPH USA, Ltd; 2016.

16. Jaworski R, Kansy A, Dzierzanowska-Fangrat K, Maruszewski B. Antibiotic prophylaxis in pediatric cardiac surgery: where are we and where do we go? A systematic review. Surgical infections. 2019;20(4):253-60.

17. Wang H, Sherwin C, Gobburu JV, Ivaturi V. Population pharmacokinetic modeling of gentamicin in pediatrics. The Journal of Clinical Pharmacology. 2019;59(12):1584-96.

18. Kanesen D, Rosman AK, Kandasamy R. Giant occipital encephalocele with Chiari Malformation type 3. Journal of neurosciences in rural practice. 2018;9(04):619-21.

19. Kumar V, Kulwant SB, Saurabh S, Richa SC. Giant occipital meningoencephalocele in a neonate: A therapeutic challenge. Journal of pediatric neurosciences. 2017;12(1):46.

20. Alqadhi S, Khan UA. SURGICAL MANAGEMENT \& CLINICAL OUTCOME OF OCCIPITAL ENCEPHALOCOELE. Journal of University Medical \& Dental College. 2017;8(2):6-10. 